\title{
PENGATURAN PENYELENGGARAAN IBADAH UMRAH DALAM PERSPEKTIF HAK ATAS KESEHATAN
}

\author{
${ }^{1}$ Asep Kusnali, ${ }^{2}$ Rustika, ${ }^{3}$ Riati Anggriani, ${ }^{4}$ Siti Maimunah, ${ }^{5}$ Haris Budiman \\ 1,2,3 Puslitbang Humaniora dan Manajemen Kesehatan, \\ J1. Percetakan Negara No. 29, Jakarta Pusat \\ ${ }^{4}$ Badan Pembinaan Ideologi Pancasila, J1. Veteran III No. 2, Jakarta Pusat \\ ${ }^{5}$ Fakultas Hukum Universitas Kuningan, J1. Cut Nyak Dhien No. 36A, Kuningan \\ Email: asep.kusnali@kemkes.com,rustika@kemkes.go.id, riati.anggriani@kemkes.go.id
}

\begin{abstract}
:
The government has issued regulations to ensure the health of Umrah pilgrims however there is no standard of health care for the Umrah pilgrims, either before departing, while traveling and in Saudi Arabia or returning to Indonesia. This study analyzes the Umrah health regulations and their implementation in the perspective of the rights to health. This research is a legal research design with sociological jurisprudence because the object under study is the application of law. The results of this study have explained that the right to health of Umrah pilgrims has been guaranteed in Law no. 8 of 2019 concerning the Implementation of Hajj and Umrah. However, there are still obstacles in the implementation which are the responsibility of the Umrah Travel Organizer, so it is necessary to make a policy by the ministry that organizes affairs in the health sector after carrying out affairs in the field of religion.
\end{abstract}

Keywords: right to health; umrah

\begin{abstract}
Abstrak:
Pemerintah telah menerbitkan beberapa peraturan untuk menjamin kesehatan jemaah umrah namun belum ada standar pelayanan kesehatan yang khusus ditujukan bagi jemaah umrah baik sebelum berangkat, saat di perjalanan, saat di Arab Saudi maupun saat kembali ke Indonesia. Penelitian ini menganalisis pengaturan pelayanan kesehatan bagi jemaah umrah dan implementasinya dalam perspektif hak atas kesehatan. Penelitian hukum ini menggunakan desain sociological jurispridence karena objek yang diteliti adalah penerapan hukum. Hasil penelitian menunjukkan bahwa UU No. 8 Tahun 2019 tentang Penyelenggaraan Ibadah Haji dan Umrah telah menjamin hak atas kesehatan jemaah umrah. Namun masih ada kendala dalam pelaksanaan yang menjadi tanggung jawab Penyelenggara Perjalanan Ibadah Umrah, sehingga perlu dibuat kebijakan dalam oleh kementerian yang menyelenggarakan urusan pemerintahan di bidang kesehatan setelah berkoordinasi dengan kementerian yang menyelenggarakan urusan pemerintahan di bidang agama.
\end{abstract}

Kata Kunci: hak atas kesehatan; umrah 


\section{Latar Belakang}

Wisata religi telah memainkan peran utama dalam menarik wisatawan untuk melakukan perjalanan keagamaan komunitas Muslim, salah satunya umrah. ${ }^{1}$ Setiap tahun, hampir 2,5 juta Muslim menghadiri haji di Mekkah dimana sekitar 1,8 juta di antaranya adalah peziarah asing yang datang dari lebih dari 180 negara di seluruh dunia. ${ }^{2}$ Berdasarkan laporan yang dikeluarkan oleh Kementerian Haji dan Umrah Arab Saudi, jumlah jemaah umrah pada semester pertama tahun 2017 mengalami peningkatan, hal ini dapat dilihat dari jumlah visa yang diberikan kepada para jemaah mencapai 6,75 juta, sedangkan tahun sebelumnya hanya 6,39 juta. ${ }^{3}$ Jika dibandingkan dengan negara lain, Indonesia berada pada posisi ketiga setelah Mesir dan Pakistan dengan kenaikan sebesar 25 persen atau 875,958 jemaah. ${ }^{4}$ Tahun 2018, Kementerian Agama mencatat total jemaah umrah Indonesia mencapai satu juta lebih orang. ${ }^{5}$
Pertemuan massal seperti ibadah keagaaman tersebut dapat menimbulkan risiko besar yang menjadi tantangan kesehatan masyarakat. Hal ini dikarenakan jemaah umrah merupakan kelompok berisiko tinggi terhadap penyakit menular, penyakit tidak menular dan kematian atas penyakit-penyakit tersebut. ${ }^{6}$ Menurut data dari Kementerian Kesehatan Saudi Arabia, penyakit jantung dan gagal jantung merupakan penyebab kematian tertinggi pada jamaah yaitu sebesar 56\%. Sementara untuk kasus yang mendapatkan rawat inap tertinggi terjadi pada kasus infeksi yaitu sebesar $37 \%{ }^{7}$

Selama ini penyelenggaraan umrah di Indonesia menjadi tanggung jawab Penyelenggara Perjalanan Ibadah Umrah (PPIU). Namun penyelenggaraan pembinaan, pelayanan dan perlindungan kesehatan jemaah umrah belum diatur kewenangannya secara teknis, apakah menjadi tanggung jawab PPIU sepenuhnya atau Pemerintah. Tidak adanya payung hukum dalam melaksanakan tujuan

1 Saber Yezli et al., "Prevention of Meningococcal Disease during the Hajj and Umrah Mass Gatherings: Past and Current Measures and Future Prospects," International Journal of Infectious Diseases 47 (2016), hlm. 61.

2 Dipti Patel, "The Hajj and Umrah: Health Protection Matters," Travel Medicine Infectious Diseases 19 (2017), https://doi.org/https://doi.org/10.1016/j.tmaid.2017.10.013, diakses tanggal 21 Desember 2020

3 Tempo.co, “Jemaah Umrah Ramadan 2017 Naik, Indonesia Terbanyak Kedua," June 26, 2017, https:/dunia. tempo.co/read/887362/jemaah-umrah-ramadan-2017-naik-indonesia-terbanyak-kedua, diakses tanggal 21 Desember 2020

4 Kementerian Agama RI, "Berapa Jemaah Umrah Dari Indonesia?,” March 3, 2017, https://databoks.katadata. co.id/datapublish/2017/03/03/berapa-jamaah-umrah-indonesia, diakses tanggal 25 Desember 2020

5 Dwi Hadya Jayani, “Arab Batalkan Umrah, Berapa Jemaah Indonesia?,” March 5, 2020, https://databoks. katadata.co.id/datapublish/2020/03/05/arab-batalkan-umrah-berapa-jemaah-umrah-indonesia, diakses tanggal 25 Desember 2020.

6 Saber Yezli et al., "Knowledge, Attitude and Practice of Pilgrims Regarding Heat-Related Illnesses during the 2017 Hajj Mass Gathering," International Journal of Environmental Research and Public Health 16, no. 17 (September 3, 2019):, hlm. 7.

7 A. Salmon-Rousseau et al., "Hajj-Associated Infections," Medicine et Maladies Infectieuses 46, no. 7 (2016), hlm. 351 
penyelenggaraan ibadah umrah sebagaimana amanat dapat menyebabkan lemahnya perlindungan kesehatan Jemaah umrah baik sebelum berangkat, dalam perjalanan maupun saat di Arab Saudi. ${ }^{8}$ Menurut International Covenant on Economic, Social and Cultural Rights (ICESCR) negara memiliki peran penting dalam menetapkan standar kesehatan tertinggi untuk masyarakatnya dan menurut International Covenant on Civil and Political Rights (ICCPR), negara harus mengambil langkah-langkah yang berkaitan dengan ancaman serius terhadap kesehatan masyarakat. ${ }^{9}$ Salah satu contohnya saat ini adalah bagaimana pandemi Covid-19 mempengaruhi kebijakan penyelenggaraan ibadah umrah di dunia sejak tahun 2019, karena Arab Saudi mengambil langkah menangguhkan sementara izin visa kegiatan ibadah umrah.Beberapa penelitian yang mirip lebih banyak menganalisis perlindungan hukum jemaah haji dalam masa tunggu, ${ }^{10}$ perlindungan hukum jemaah haji dalam pelaksanaan di daerah karena adanya kekosongan hukum di tingkat daerah, ${ }^{11}$ perlindungan hukum pemohon haji dan umrah dalam sudut pandang nilai keadilan, ${ }^{12}$ perlindungan hukum jemaah umrah dalam konteks perlindungan konsumen, ${ }^{13}$ dan perlindungan kesehatan jemaah umrah dalam konteks faktor risiko dalam ilmu kesehatan dan manajemen. ${ }^{14}$ Dalam tulisan ini akan memberikan wawasan berbeda dengan melihat perkembangan hukum dalam perlindungan hak atas kesehatan jemaah umrah sejak diundangkannya Undang-Undang No. 17 Tahun 1999 tentang Penyelenggaraan Ibadah Haji (UU No. 17/1999), Undang-Undang No. 13 Tahun 2008 tentang Penyelenggaraan Ibadah Haji (UU No. 13/2008) dan terakhir Undang-Undang No. 8 Tahun 2019 tentang Penyelenggaraan Ibadah Haji dan Umrah (UU No. 8/2019).

\section{Pembahasan}

\section{A. Instrumen Hukum Internasional Mengenai Hak Atas Kesehatan}

Hak atas kesehatan termasuk dalam hak asasi manusia generasi kedua yang sangat membutuhkan peran aktif negara yang

8 Dede Anwar Musadad, "Kebijakan Pelayanan Kesehatan Jemaah Umrah," in Penyelenggaraan Pelayanan Kesehatan Pada Ibadah Umrah, ed. Rustika (Jakarta: LIPI Press, 2018), hlm. 16.

9 United Nations High Commissioner for Human Rights (UNHCHR) \& World Health Organization (WHO), "The Right to Health" (New York, 2008).

10 Mariani et al., "The Determination of Waiting Listed Pilgrim Candidates Criteria in Hajj Enforcement System in Indonesia," Journal of Law, Policy and Globalization 48, no. 2 (2016), hlm. 180.

11 Achmad Irwan Hamzani, Siswanto Siswanto, and Havis Aravik, "Legal Protection for Hajj Pilgrims Through Regional Regulation," Mazahib 17, no. 2 (2018), hlm. 61.

12 Zaenul Arifin, Ahmad Rofiq, and Widayati, "Reconstruction of Legal Protection for Hajj and Umrah Applicant in Indonesia Based on Justice Value," International Journal of Advanced Research 8, no. 02 (2020), hlm. 1375.

13 Sihabudin Mukhlis, "Perlindungan Hukum Jemaah Umrah Dalam Penyelenggaraan Perjalanan Ibadah Umrah," Asy-Syaria'ah 20, no. 1 (2018), hlm. 50.

14 Eka Jusup Singka and Innes Ericca, "Hajj Health Management in Indonesia," Medical Journal of Indonesia 29, no. 2 (2020), hlm 117, lihat juga Rustika, Herti Windya Puspasari, and Asep Kusnali, "Analisis Kebijakan Pelayanan Vaksinasi Meningitis Jemaah Umrah Di Indonesia," Buletin Penelitian Sistem Kesehatan 21, no. 1 (2018), hlm. 61 
menekankan tidak hanya pada pemenuhan hak masyarakat namun juga kewajiban masyarakat. ${ }^{15}$ Secara umum, hak atas kesehatan tercantum dalam The Universal Declaration of Human Rights Pasal 25 ayat (1) yang menyebutkan bahwa "Everyone has a right to a standard of living adequate for the health of himself and his family, including food, clothing, housing, and medical care and necessary social services....". ${ }^{16}$ Pasal tersebut menyiratkan bahwa hak atas kesehatan berlaku secara luas hingga hubungan sosial, tidak terbatas pada sehat secara fisik saja. Studi epidemiologi yang menekankan pada faktor-faktor risiko yang berbasis individu menjelaskan bahwa penyebab mendasar timbulnya suatu penyakit karena adanya faktor sosial ekonomi dan dukungan sosial sehingga hal tersebut menjadi salah satu alasan diperlukannya perhatian besar terhadap kondisi sosial. ${ }^{17}$ Negara dalam hal ini Pemerintah memiliki kewajiban utama untuk melindungi dan mempromosikan hak asasi manusia.

Berkaitan dengan hak atas kesehatan dalam penyelenggaraan umrah terdapat dua perjanjian internasional yang dapat dijadikan acuan yaitu, International Covenant on Civil and Political Rights (ICCPR) dan International Covenant on Economic, Social and Cultural Rights (ICESCR). ICCPR telah diratifikasi oleh 173 negara, ${ }^{18}$ sementara ICESCR telah diratifikasi oleh 171 negara. ${ }^{19}$ Kewajiban Negara terkait hak atas kesehatan yang dilindungi di bawah ICCPR, berbeda dengan kewajiban Negara terkait dengan hak atas kesehatan yang dilindungi di bawah ICESCR. Berdasarkan Pasal 2 ayat (1) $\mathrm{ICCPR}^{20}$ mewajibkan Negara untuk memastikan semua individu dalam yurisdiksi mereka memiliki hak yang diakui dalam ICCPR dan mengadopsi langkah-langkah legislatif, judisial, administratif, edukatif dan lainnya yang sesuai untuk tujuan dalam ICCPR, sedangkan dalam Pasal 2 ICESCR $^{21}$ mengharuskan Negara-negara Pihak untuk mengambil langkah-langkah secara maksimal berdasarkan sumber daya yang tersedia, dengan maksud untuk mencapai realisasi pemenuhan hak-hak secara progresif yang diakui dalam ICESCR.

ICCPR mengatur hak atas kesehatan, namun diberikan suatu pembatasan terhadap pemenuhan kesehatan masyarakat yaitu “....

15 Philip Hadjon, Perlindungan Hukum Bagi Rakyat Indonesia (Surabaya: Universitas Airlangga, 1985).

16 UN General Assembly, Universal Declaration of Human Rights, 10 December 1945, 2015.

17 Alicia Ely Yamin, "The Right to Health Under International Law and Its Relevance to the United States," American Journal of Public Health 95, no. 7 (2005), hlm. 1157.

18 United Nations, "International Covenant on Civil and Political Rights," Database of the United Nations Office of Legal Affairs (OLA), July 4, 2019, https://www.ohchr.org/Documents/HRBodies/CCPR/OHCHR_Map_ ICCPR.pdf., diakses pada tanggal 20 Desember 2020

19 United Nations, "International Covenant on Economic, Social and Cultural Rights," Database of the United Nations Office of Legal Affairs (OLA), June 19, 2020, https://www.ohchr.org/Documents/HRBodies/CESCR/ OHCHR_Map_ICESCR.pdf., diakses pada tanggal 20 Desember 2020

20 "International Covenant on Civil and Political Rights (ICCPR)" (1976), Pasal 22 ayat (1).

21 "International Covenant on Economic, Social and Cultural Rights (ICESCR)" (1976), Pasal 2. 
are necessary to protect... public health..." (Pasal 12 ayat (3)). Ketentuan tersebut merupakan salah satu contoh hak asasi manusia yang mengakomodasi adanya kewajiban dalam menjalankan kesehatan masyarakat berupa tindakan karantina saat terjadinya epidemi. Ketentuan tersebut memungkinkan kesehatan masyarakat dijadikan sebagai dasar untuk membatasi hak-hak tertentu yang dapat memungkinkan negara mengambil langkahlangkah yang berkaitan dengan ancaman serius terhadap kesehatan masyarakat. ${ }^{22}$ Langkahlangkah ini harus secara khusus ditujukan untuk mencegah penyakit atau cedera maupun dalam memberikan perawatan. ${ }^{23}$ Kesehatan masyarakat juga dapat menjadi alasan yang dapat dibenarkan untuk membatasi perjalanan internasional dan untuk itu negara memiliki peran penting dalam menetapkan standar kesehatan tertinggi masyarakatnya berdasarkan kondisi demografi, epidemiologis dan kondisi ekonomi. ${ }^{24}$

Hal ini dapat dipahami bahwa hak atas kesehatan sebagai hak untuk sistem kesehatan yang efektif dan terintegrasi yang mencakup perawatan kesehatan dan faktorfaktor lain yang mempengaruhi kesehatan yang tanggap terhadap priositas nasional dan lokal dan dapat diakses oleh semua orang.
Untuk memperjelas operasionalisasi hak atas kesehatan dalam ICESCR, UN Committee on Economic, Social and Cultural Rights memonitor kepatuhan pelaksanaan ICESCR melalui General Comment on the Right to Health dalam 4 (empat elemen), antara lain ${ }^{25}$ (1) Availability, yang dimaksudkan untuk melihat keberfungsian program kesehatan masayarakat dan ketersediaan fasilitas pelayanan kesehatan termasuk didalamnya adalah sumber daya dalam jumlah yang cukup; (2) Accessibility, berupa fasilitas kesehatan, akses barang publik dan jasa pelayanan kesehatan yang dapt diakses oleh setiap orang. Terdapat 4 (empat) dimensi dalam accessibility yaitu tidak diskriminatif, terjangkau secara fisik, terjangkau secara ekonomi dan informasi yang terjangkau; (3) Acceptability, dimaksudkan agar semua fasilitas kesehatan, penyediaan barang dan jasa harus diterima oleh etika medis dan diterima secara budaya termasuk hal sensitif pada gender dan siklus hidup; dan (4) Quality, yang maksudnya agar fasilitas kesehatan, barang dan jasa, baik secara keilmuan maupun praktik medis dalam kualitas yang baik.

Dengan memperhatikan ketentuan di atas, maka setiap gangguan, ketidakadilan atau apapun bentuknya yang dapat menyebabkan

22 Stephen P. Marks, The Emergence and Scope of the Human Right to Health, ed. Jose M. Zuniga, Stephen P. Marks, and Lawrence O. Gostin, Advancing the Human Right to Health (Oxford: Oxford University Press, 2013), hlm. 15-16.

23 United Nations, Economic and Social Council, U.N. Sub-Commission on Prevention of Discrimination and Protection of Minorities, Siracusa Principles on the Limitation and Derogation of Provisions in the International Covenant on Civil and Political Rights (Annex, UN Doc E/CN.4/1984/4. Paragraf 25, 1984).

24 Alicia Ely Yamin, Loc.cit.

25 United Nations High Commissioner for Human Rights (UNHCHR) \& World Health Organization (WHO), "The Right to Health." (New York, 2008), hlm. 4 
ketidak-sehatan tubuh manusia, jiwa, masyarakat merupakan kesehatan kolektif lingkungan alam dan lingkungan sosial sehingga salah seorang menerima manfaat termasuk produkhukum danmanajemensosial tidak dapat mencegah orang lain untuk yang diterima merupakan suatu pelanggaran hak asasi manusia. Dan upaya untuk menghormati, melindungi dan memenuhi hak atas kesehatan merupakan kewajiban negara untuk dapat mengimplementasikan norma-norma hak asasi manusia pada hak atas kesehatan.

\section{B. Hak Atas Kesehatan dalam Penyelenggaraan Ibadah Umrah di Indonesia}

Kesehatan merupakan hak asasi manusia yang perlu diatur secara eksplisit dalam konstitusi. Hal ini dimaksudkan untuk tecapai atau terpeliharanya kepentingan nasional, keutuhan wilayah nasional, persatuan bangsa, kemakmuran, dan kelangsungan hidup bangsa Indonesia di masa mendatang. ${ }^{26}$ UndangUndang Dasar Negara Republik Indonesia Tahun 1945 (UUD NRI Tahun 1945) telah membagi kategori kesehatan sebagai public goods dan private goods. Kesehatan sebagai public goods terdapat dalam ketentuan Pasal $28 \mathrm{H}$ ayat (2) dan ayat (3) yang merupakan kesehatan masyarakat. Hal ini dikarenakan (1) penyediaan kesehatan publik berkaitan erat dengan tindakan pemerintah, (2) kesehatan mendapatkan manfaat yang sama, (3) adanya kesempatan bagi semua untuk hidup dalam kondisi untuk meningkatkan kesehatan serta meminimalkan perbedaan kesehatan antar kelompok, dan (4) penyediaan kesehatan masyarakat tergantung pada global public goods yang mungkin memerlukan solusi universal. $^{27}$

Kesehatan sebagai private goods terdapat dalam ketentuan Pasal 28H ayat (1) UUD NRI Tahun 1945 yang berarti bahwa masyarakat diberikan pilihan untuk memperoleh kesejahteraan hidupnya, memiliki tempat tinggal, lingkungan hidup yang baik serta mendapatkan pelayanan kesehatan yang tidak dibatasi oleh anggaran Pemerintah, dengan kata lain peran swasta dalam pelayanan kesehatan dapat membantu mengurangi pengeluaran Pemerintah $^{28}$ dan tergantung pada seberapa besar tindakan individu dipengaruhi oleh kekuatan struktural, sosial dan politik sehingga kesehatan menjadi private goods, ${ }^{29}$ seperti risiko kesehatan yang diakibatkan oleh penyakit katastropik yang tidak dapat sepenuhnya dikendalikan, sehingga satu-satunya solusi adalah berbagi

26 Majelis Permusyawaratan Rakyat Republik Indonesia (MPR RI), Risalah Perubahan Undang-Undang Dasar Negara Republik Indonesia Tahun 1945, Tahun Sidang 2000. Buku Dua (Jakarta: Sekretariat Jenderal Majelis Permusyawaratan Rakyat Republik Indonesia, 2010). hlm. 426

27 Sandro Galea, "Public Health as a Public Good ," January 10, 2016, https://www.bu.edu/sph/2016/01/10/ public-health-as-a-public-good/., diakses pada tanggal 7 November 2020

28 Tejvan Pettinger, "Healthcare - Private vs Public Sector ," January 17, 2019, https://www.economicshelp.org/ blog/1777/economics/health-care-arguments/., diakses pada tanggal 7 November 2020

29 Sandro Galea, Loc.cit. 
risiko antara Pemerintah dan masyarakat. Hal ini menyebabkan terjadinya pergeseran sifat kesehatan yang semula public goods menjadi private goods. ${ }^{30}$

Secara implisit, hak atas kesehatan merupakan bagian dari hak hidup yang terkandung dalam ketentuan Pasal 28A UUD NRI Tahun 1945. ${ }^{31}$ Untuk melindungi, menghormati, dan memenuhi hak atas kesehatan pada hakikatnya tidak hanya merupakan kewajiban Pemerintah namun juga kewajiban setiap orang. Berdasarkan ketentuan Pasal 28I ayat (4) UUD NRI Tahun 1945 yang berbunyi: "Perlindungan, pemajuan, penegakan, dan pemenuhan hak asasi manusia adalah tanggung jawab negara, terutama pemerintah", maka dalam hal adanya frasa 'tanggung jawab negara' maka dapat di artikan tidak hanya menjadi tanggung jawab pemerintah namun menjadi tanggung jawab negara, yang dalam konteks negara ini yang dimaksudkan adalah baik eksekutif, legislatif, dan lembaga-lembaga tinggi lainnya ikut bertanggung jawab. ${ }^{32}$ Negara dalam hal ini termasuk dalam pengertian yang luas yaitu meliputi pula society dengan kata lain Negara itu merupakan sebuah komunitas yang secara logika dan historisnya telah menyebabkan terbentuk dan berkembangnya Negara. ${ }^{33}$

Secara eksplisit, hak atas kesehatan diatur dalam Undang-Undang No. 39 Tahun 1999 tentang Hak Asasi Manusia, yang tercakup dalam ketentuan hak untuk hidup dalam Pasal 9 bahwa setiap orang berhak untuk hidup, mempertahankan hidup dan meningkatkan taraf kehidupannya; berhak hidup tenteram, aman, damai, bahagia, sejahtera lahir dan batin; dan berhak atas lingkungan hidup yang baik dan sehat. Selain itu, makna hak atas kesehatan tercakup dalam hak atas jaminan sosial (Pasal 41) dimana setiap warga negara berhak atas jaminan sosial yang dibutuhkan untuk hidup layak serta untuk perkembangan pribadinya secara utuh.

Pengaturan hak atas kesehatan jemaah umrah mengalami beberapa kali pergantian (Tabel 1). Perubahan tersebut tidak lepas dari aspek politik hukum dengan memperhatikan aspek kepentingan nasional, ${ }^{34}$ sehingga Pemerintah perlu melakukan beberapa

30 Philip Musgrove, Public and Private Roles in Health: Theory and Financing Patterns (Washington D.C: The World Bank, 1996). hlm. 14

31 Mahkamah Konstitusi Republik Indonesia (MK), Naskah Komprehensif Perubahan Undang-Undang Dasar Negara Republik Indonesia Tahun 1945, Latar Belakang, Proses, Dan Hasil Pembahasan 1999-2002 (Jakarta: Sekretariat Jenderal dan Kepaniteraan Mahkamah Konstitusi, 2010). hlm. 313

32 Majelis Permusyawaratan Rakyat Repunlik Indonesia (MPR RI), Risalah Perubahan Undang-Undang Dasar Negara Republik Indonesia Tahun 1945, Tahun Sidang 2000. Buku Tujuh (Jakarta: Sekretariat Jenderal Majelis Permusyawaratan Rakyat Republik Indonesia, 2010). hlm. 247 dalam Roberia, "Paradigma Jaminan Kesehatan Nasional: Konstruksi Jaminan Kesehatan Bagi Seluruh Rakyat Indonesia Dalam Mewujudkan Negara Kesejahteraan Menurut Konstitusi Indonesia" (Universitas Indonesia, 2013)

33 Hans Kelsen, General Theory of Law and State. Translated by Anders Wedberg (New York: Russel \& Russel, 1961); Mikho Ardinata, "Tanggung Jawab Negara Terhadap Jaminan Kesehatan Dalam Perspektif Hak Asasi Manusia," Jurnal HAM 11, no. 2 (2020), hlm. 323

34 Ardiansah and Silm Oktapiani, "Politik Hukum Pemenuhan Hak Atas Kesehatan Rakyat Indonesia Berdasarkan UU SJSN Dan Undang-Undang BPJS," Jurnal IUS Kajian Hukum Dan Keadilan, Vol. 8, No. 1, April 2020, hlm 169-170. 
Tabel 1. Perkembangan Pengaturan Hak Atas Kesehatan Jemaah Umrah

\begin{tabular}{|c|c|c|c|}
\hline Aspek & UU No. 17/1999 & UU No. 13/2008 & UU No. 8/2019 \\
\hline Asas & $\begin{array}{l}\text { Penyelenggaraan ibadah } \\
\text { haji berdasarkan asas } \\
\text { keadilan memperoleh } \\
\text { kesempatan, } \\
\text { perlindungan, dan } \\
\text { kepastian hukum sesuai } \\
\text { dengan Pancasila dan } \\
\text { Undang-Undang Dasar } \\
\text { 1945. (Pasal 4) }\end{array}$ & $\begin{array}{l}\text { Penyelenggaraan Ibadah } \\
\text { Haji dilaksanakan } \\
\text { berdasarkan asas } \\
\text { keadilan, profesionalitas, } \\
\text { dan akuntabilitas dengan } \\
\text { prinsip nirlaba. (Pasal 2) }\end{array}$ & $\begin{array}{l}\text { Penyelenggaraan Ibadah Haji dan } \\
\text { Umrah berasaskan: (a). Syariat, } \\
\text { (b). Amanah, (c). Keadilan, (d). } \\
\text { Kemaslahatan, (e). Kemanfaatan, } \\
\text { (f). Keselamatan, (g). Keamanan, } \\
\text { (h). Profesionalitas, (i). } \\
\text { Transparansi, dan (j). akuntabilitas. } \\
\text { (Pasal 2) }\end{array}$ \\
\hline Tujuan & $\begin{array}{l}\text { Memberikan pembinaan, } \\
\text { pelayanan, dan } \\
\text { perlindungan bagi jemaah } \\
\text { haji (Pasal 5) }\end{array}$ & $\begin{array}{l}\text { Memberikan pembinaan, } \\
\text { pelayanan, dan } \\
\text { perlindungan bagi jemaah } \\
\text { haji (Pasal 3) }\end{array}$ & $\begin{array}{l}\text { Memberikan pembinaan, } \\
\text { pelayanan, dan pelindungan bagi } \\
\text { Jemaah Haji dan Jemaah Umrah } \\
\text { dan mewujudkan kemandirian dan } \\
\text { ketahanan dalam Penyelenggaraan } \\
\text { Ibadah Haji dan Umrah (Pasal 3) }\end{array}$ \\
\hline PPIU & $\begin{array}{l}\text { Penyelenggara perjalanan } \\
\text { ibadah umrah adalah } \\
\text { masyarakat dan } \\
\text { ditetapkan oleh Menteri. } \\
\text { (Pasal } 24 \text { ayat (3)) }\end{array}$ & $\begin{array}{l}\text { Penyelenggara perjalanan } \\
\text { Ibadah Umrah dilakukan } \\
\text { oleh Pemerintah dan/atau } \\
\text { biro perjalanan wisata } \\
\text { yang ditetapkan oleh } \\
\text { Menteri. (Pasal } 43 \text { ayat } \\
\text { (2)) }\end{array}$ & $\begin{array}{l}\text { Penyelenggaraan perjalanan Ibadah } \\
\text { Umrah dilakukan oleh PPIU (Pasal } \\
86 \text { ayat (2)) dan Pemerintah dapat } \\
\text { menyelenggarakan perjalanan } \\
\text { Ibadah Umrah (Pasal } 86 \text { ayat (3)) } \\
\text { jika terdapat keadaan luar biasa } \\
\text { atau kondisi darurat (Pasal } 86 \\
\text { ayat (4)) yang ditetapkan Presiden } \\
\text { (Pasal } 86 \text { ayat (5). }\end{array}$ \\
\hline $\begin{array}{l}\text { Hak atas } \\
\text { kesehatan } \\
\text { jemaah } \\
\text { umrah }\end{array}$ & $\begin{array}{l}\text { Mendapatkan } \\
\text { pelayanan kesehatan } \\
\text { dari petugas kesehatan } \\
\text { yang disediakan oleh } \\
\text { penyelenggara perjalanan } \\
\text { ibadah umrah (Pasal } 25 \\
\text { ayat (1)). }\end{array}$ & $\begin{array}{l}\text { Mendapatkan pelayanan } \\
\text { kesehatan dari petugas } \\
\text { kesehatan yang } \\
\text { disediakan penyelenggara } \\
\text { perjalanan Ibadah Umrah } \\
\text { (Pasal 45). }\end{array}$ & $\begin{array}{l}\text { Mendapatkan layanan kesehatan } \\
\text { yang disediakan oleh PPIU (Pasal } \\
88 \text { ) dan mendapatkan pelindungan } \\
\text { jiwa, kecelakaan, dan kesehatan } \\
\text { dalam bentuk asuransi. (Pasal } \\
96 \text { ayat (1) butir d jo. Pasal } 97 \\
\text { ayat (1)) sesuai dengan kebijakan } \\
\text { Menteri Agama (Pasal } 96 \text { ayat (3)) }\end{array}$ \\
\hline
\end{tabular}

langkah strategis untuk melindungi kesehatan jemaah umrah di Indonbesia. Terakhir melalui UU No. 8/2019 secara implisit menjamin hak atas pelayanan kesehatan jemaah umrah. Pembentukan norma tersebut dapat menjadi kekuatan terjadinya perubahan pola perilaku kesehatan jemaah umrah dalam hal kemandirian dalam kesehatan dan beribadah sekaligus memberikan perlindungan hukum ${ }^{35}$ selama penyelenggaraan ibadah umrah yang tidak hanya bersifat adaptif dan flekibel, namun bisa prediktif dan antisipatif. ${ }^{36}$

Sejak tahun 1999 hak atas kesehatan jemaah umrah diatur pada tingkat Keputusan Menteri Agama No. 371 Tahun 2002 tentang Penyelenggaraan Ibadah Haji dan Umrah sebagaimana telah diubah dengan Keputusan Menteri Agama No. 396 Tahun 2003 dan secara teknis diatur dalam Keputusan Direktur Jenderal Bimbingan Masyarakat Islam Dan 
Penyelenggaraan Haji No. D/348 Tahun 2003

Tentang Perubahan Atas Keputusan Direktur

Jenderal Bimbingan Masyarakat Islam

Dan Penyelenggraan Haji Nomor D/377/

Tahun 2002 Tentang Petunjuk Pelaksanaan

Penyelenggaraan Ibadah Haji dan Umrah terbatas pada kewajiban PPIU menyediakan layanan kesehatan dengan menyediakan petugas kesehatan disamping petugas pembimbing ibadah, dan penyediaan petugas pendamping jika terdapat jemaah yang sakit di Rumah Sakit Arab Saudi. Selanjutnya diatur sesuai dengan perjanjian penyelenggaraan ibadah umrah antara jemaah dengan PPIU.

Mulai tahun 2008 hak atas kesehatan jemaah umrah diatur melalui Peraturan Pemerintah No. 79 Tahun 2012 tentang Pelaksanaan Undang-Undang Nomor 13 Tahun 2008 Tentang Penyelenggaraan Ibadah Haji (PP No. 79/2012) dan Peraturan Menteri Agama RI No. 8 Tahun 2018 Tentang Penyelenggaraan Perjalanan Ibadah Umrah (PMA No. 8/2018). ${ }^{37}$ PPIU berkewajiban memberikan pembinaan, pelayanan dan perlindungan kesehatan bagi jemaah sebelum pemberangkatan ke dan dari Arab Saudi dan selama di Arab Saudi (Pasal 17 ayat (1) dan (2) PMA No. 8/2018).

Aspek pelayanan yang harus dipenuhi PPIU meliputi: (a) Menyediakan tenaga kesehatan, $^{38}$ (b) Menyediakan obat-obatan, (c) Memeriksakan kondisi kesehatan jemaah saat awal sebelum berangkat, (d) Pengurusan jemaah yang sakit selama di perjalanan dan di Arab Saudi, (e) Pengurusan jemaah meninggal dunia, dan (f) Bimbingan kesehatan jemaah diberikan sebelum diberangkatkan ke dan dari Arab Saudi dan selama di Arab Saudi.

Aspek perlindungan kesehatan jemaah umrah dilakukan PPIU dengan memastikan jemaah mendapatkan vaksinasi meningitis (Pasal 17 ayat (3) PMANo. 8/2018) disamping memberikan perlindungan yang meliputi asuransi jiwa, kesehatan dan kecelakaan (Pasal 20 ayat (1) butir a PMANo. 8/2018). Pemberian vaksin meningitis merupakan syarat mutlak bagi semua calon jemaah haji dan umrah yang akan memasuki kawasan Kerajaan Arab Saudi. Ketentuan ini dibahas dalam Nota Diplomatik Kedutaan Besar Kerajaan Arab Saudi di Jakarta No. 211/94/71/577 tanggal 1 Juni 2006. Karena pihak Kedutaan Arab Saudi hanya akan mengeluarkan visa perjalanan setelah vaksinasi dilakukan. ${ }^{39}$

Pemberian vaksin meningitis merupakan kewajiban bagi setiap orang yang melakukan perjalanan internasional dari dan ke negara terjangkit dan/atau endemis untuk penyakit tertular tertentu dan/atau atas permintaan negara tujuan sebagaimana diatur dalam Pasal 2 ayat (1) Peraturan Menteri Kesehatan No. 23 Tahun 2018 tentang Pelayanan dan

37 PMA No. 8 Tahun 2018 merupakan peraturan yang menggantikan Peraturan Menteri Agama No. 18 Tahun 2015 tentang Penyelenggaraan Perjalanan Ibadah Umrah

38 Jumlah petugas kesehatan dapat dilihat dalam Pasal 21 ayat (3) PMA No. 8/2018 dimana proporsi 1 petugas kesehatan adalah untuk 90 jemaah umrah

39 Kementerian Kesehatan RI, "Seluruh Jemaah Haji Dan Petugas Akan Divaksinasi Meningitis.”, Loc.cit. 
Penerbitan Sertifikat Vaksinasi Internasional (PMK No. 23/2018) yang hanya dapat dilakukan oleh Kantor Kesehatan Pelabuhan, Klinik atau Rumah Sakit yang telah memenuhi persyaratan (Pasal 2 ayat (2) PMK No. 23/2018). Berdasarkan Peraturan Menteri Kesehatan No. 12 Tahun 2017 tentang Penyelenggaraan Imunisasi (PMK No. 12/2017), disebutkan bahwa pemberian imunisasi meningitis meningokokus diberikan minimal 30 hari sebelum keberangkatan umroh. Hal ini bertujuan agar antibodi setelah vaksin diberikan kepada jemaah umrah dapat terbentuk dengan sempurna dan aktif dalam melindungi para jamaah dari penyakit meningitis meningokokus selama menjalankan ibadah dan saat kembali ke tanah air. $^{40}$

Selain untuk menghindari infeksi, pemberian vaksin meningitis juga menghindari wabah penyakit yang jika dilaksanakan sesuai kesadaran dan tindakan profilaksis. Hal ini telah diantisipasi oleh Kementerian Kesehatan Arab Saudi dengan menerbitkan kondisi kesehatan jemaah untuk visa masuk haji dan umrah setiap tahun sejak 2008. Demikian juga dengan WHO dan Institut Prancis untuk Pengawasan Kesehatan Masyarakat setiap tahun mempublikasikan persyaratan kesehatan untuk peziarah ke Mekah. ${ }^{41}$
Berdasarkan uraian di atas menjelaskan bahwa pemenuhan hak atas kesehatan jemaah umrah harus memenuhi tujuan penyelenggaraan ibadah umrah dari aspek pembinaan, pelayanan dan perlindungan kesehatan yang dilaksanakan oleh PPIU selaku penyelenggara dan Pemerintah selaku regulator. Untuk melaksanakan tujuan tersebut maka perlu adanya fasilitasi dengan membentuk aturan teknis (by giving regulation) disamping penegakkan hukum (by law enforcement) agar timbulnya hak dan kewajiban serta jaminan terhadap subjek hukum. ${ }^{42}$

\section{Evaluasi Pemenuhan Hak Atas Kesehatan Jemaah Umrah}

Risiko kesehatan yang menimpa jemaah umrah pada dasarnya sama dengan risiko kesehatan jemaah haji yang dapat mengancam kemananan negara dalam bidang kesehatan karena terjadi keluar dan masuknya penyakit antarnegara. ${ }^{43}$ Banyak faktor yang mempengaruhi pemenuhan hak atas kesehatan jemaah umrah dalam rangkaian menjalankan ibadah umrah, antara lain usia jemaah umrah yang kebanyakan berusia lanjut, pengetahuan jemaah umrah yang tentang risiko kesehatan yang mungkin timbul selama menjalankan ibadah umrah masih kurang, kondisi iklim dan cuaca di Arab Saudi yang berbeda

\footnotetext{
40 Rhezka Imaniar Fitranto, Andri Dwi Hernawan, and Mardjan, "Analisis Faktor Yang Berhubungan Dengan Ketepatan Waktu Vaksinasi Meningitis Meningokokus Calon Jemaah Umrah Di KKP Pontianak," Journal of Health Epidemiology and Communicable Diseases 5, no. 2 (2019), hlm. 70
}

41 A. Salmon-Rousseau et al., Loc.cit.

42 Sihabudin Mukhlis, Op.cit., hlm. 51

43 Dede Anwar Musadad, Op.cit. hlm. 19 
dengan kondisi di Indonesia, serta penyakit yang sedang diderita jemaah menjadikan risiko kesehatan Jemaah umrah menjadi cukup besar. ${ }^{44}$ Hal ini menyebabkan masih banyaknya jemaah umrah yang bermasalah kesehatan saat menjalankan ibadah umrah sehingga diperlukannya perlindungan hak atas kesehatan jemaah umrah..

Dalam konteks perlindungan konsumen dimana perlindungan hak atas kesehatan jemaah umrah merupakan bagian dari perlindungan hukum yang wajib diberikan Negara. ${ }^{45}$ Sudikno Mertokusumo ${ }^{46}$ membagi dua cara pemberian perlindungan hukum tersebut kepada masyarakat, antara lain perlindungan hukum preventif dan perlindungan hukum represif. Perlindungan hukum terhadap kesehatan jemaah umrah merupakan perlindungan hukum secara sifat preventif. Implementasi perlindungan hukum terhadap kesehatan jemaah umrah tidak jauh berbeda dengan penyelenggaraan ibadah haji, yang harus sudah dilakukan melalui rangkaian pembinaan, pelayanan dan perlindungan bidang kesehatan.

\section{Pembinaan Kesehatan}

Pembinaan kesehatan dapat terlaksana jika terdapat data hasil pemeriksaan kesehatan kesehatan jemaah umrah untuk mendeteksi faktor risiko dalam memberikan pelayanan kesehatan jemaah umrah. ${ }^{47}$ Dalam implementasinya belum semua PPIU mewajibkan calon jemaah umrah untuk melakukan pemeriksaan kesehatan dan membawa obat-obatan untuk persediaan selama ibadah umrah. ${ }^{48}$

Pembinaan kesehatan ditujukan untuk mempersiapkan jemaah umrah untuk siap saat melaksanakan ibadah umrah dan sebagai upaya promotif dan preventif dengan memberikan pengetahuan kesehatan kepada calon jemaah umrah. Pembinaan kesehatan bagi calon anggota jemaah umrah menjadi hal yang penting sebagai bagian dari kesiapan jemaah untuk melaksanakan umrah di samping pembinaan ibadah yang biasanya dilakukan saat manasik haji. Porsi materi kesehatan sangat sedikit diberikan saat manasik haji dan bahkan selama di Arab Saudi sebagian besar PPIU tidak memberikan pembinaan kesehatan kepada jemaah umrah. Kewajiban melakukan pembinaan kesehatan dalam penyelenggaraan umrah memang tidak secara jelas diwajibkan dalam regulasi yang ada saat ini. Kewajiban pemenuhan pembinaan masih secara luas diatur dan belum dilaksanakan sepenuhnya oleh PPIU karena belum ada aturan teknis yang dapat dijalankan oleh PPIU untuk kelancaran jemaah dalam melaksanakan ibadah umrah. ${ }^{49}$

44 Herti Windya Puspasari, Tety Rachmawati, and Rustika, "Prolog: Mewujudkan Pelayanan Kesehatan Jemaah Umrah," in Penyelenggaraan Pelayanan Kesehatan Pada Ibadah Umrah, ed. Rustika (Jakarta: LIPI Press, 2018), hlm. 11

45 Sihabudin Mukhlis, Loc.cit,

46 Sudikno Mertokusumo, Penemuan Hukum (Bandung: Citra Aditya Bakti, 2009), hlm. 4.

47 Dede Anwar Musadad, Op.cit., hlm. 22

48 Rustika, "Laporan Penelitian: Implementasi Model Pelayanan Kesehatan Umrah Di Indonesia” (Jakarta, 2017), hlm. 63

$49 \mathrm{Ibid}$. 
Pentingnya pembinaan kesehatan jemaah umrah adalah untuk mengurangi beban yang akan timbul baik bagi PPIU maupun Pemerintah terutama ketika menghadapi jemaah umrah yang mengalami sakit dan/atau dirawat dalam rangkaian ibadah umrah di Arab Saudi. Karena ibadah umrah durasinya lebih singkat dibandingkan dengan ibadah haji, maka pembinaan kesehatan jemaah umrah mutlak perlu dilakukan sebelum dan selama proses ibadah umrah, agar jemaah dapat mandiri mempersiapkan fisik dan mental selama di Arab Saudi. ${ }^{50}$

\section{Pelayanan Kesehatan}

Pelayanan kesehatan umrah akan tercapai jika jemaah umrah memenuhi prasyarat yaitu sehat atau sakit yang terkontrol sebelum berangkat ke Saudi Arabia, saat dalam perjalanan pergi dan pulang, saat beribadah, dan saat kembali ke tanah air. PMA No. 8/2018 belum menjabarkan secara rinci pelayanan bagi jemaah umrah karena hal ini merupakan kewenangan Kementerian Kesehatan sehingga pemeriksaan kesehatan jemaah umrah masih terbatas pada pemberian vaksin meningitis.

Belum optimalnya perlindungan kesehatan bagi jemaah umrah disebabkan oleh belum adanya kebijakan teknis bidang kesehatan yang mengatur pembinaan, pelayanan dan perlindungan kesehatan jemaah umrah. Hal ini berdampak pada perilaku penyelenggara umrah yang masih belum dapat menyediakan tenaga pendamping kesehatan serta tidak dilakukannya dokumentasi anggota jemaah yang sakit karena tidak ada kewajiban untuk membuat laporan tersebut kepada Pemerintah. ${ }^{51}$

Upaya pemberian pelayanan kesehatan jemaah umrah selama berada di Arab Saudi sangat bervariasi. Hanya sedikit PPIU yang bersedia menyediakan petugas kesehatan dikarenakan penyediaan tenaga kesehatan membutuhkan biaya yang cukup besar yang dapat membebani biaya umrah, sehingga pengadaan tenaga kesehatan hanya jika dipenuhi bila jumlah Jemaah umrah dalam satu kelompok cukup banyak. Beberapa PPIU yang tidak dapat menyediakan tenaga kesehatan dan kebetulan terdapat anggota jemaah umrah yang merupakan tenaga kesehatan dengan sukarela memberikan pelayanan kesehatan bagi anggota jemaah umrah dalam kelompoknya yang sakit. ${ }^{52}$

PPIU yang bekerja sama dengan pelayanan kesehatan di Arab Saudi dapat memudahkan pelaksanaan PPIU jika terdapat anggota jemaah yang sakit untuk dapat dirujuk ke sarana pelayanan kesehatan yang disediakan Pemerintah Arab Saudi termasuk

50 Rustika, Tety Rachmawati, and Ratih Oemiati, "Efektifitas Pembinaan Jemaah Haji Melalui Posbindu PTM," in Prosiding Temu Ilmiah Nasional Haji Dan Umrah 2016: "Enhancing Health Promotion and Disease Prevention in Hajj Health Services. Yogyakarta, 25-26 Oktober 2016 (Jakarta: InternaPublishing, 2016), hlm. 125

51 Zaenal Abidin, Laporan Penelitian: Evaluasi Implementasi PMA 18 Tahun 2015 (Jakarta: Badan Penelitian dan Diklat Kementerian Agama, 2016).

52 Rustika (a), Op.cit., hlm. 64 
obat-obatan yang dibutuhkan jemaah umrah. Namun, Pemerintah Arab Saudi tetap merekomendasikan untuk membawa obatobatan sendiri karena sangat dimungkinkan beberapa obat yang diperlukan tidak tersedia di Arab Saudi. ${ }^{53}$

\section{Perlindungan Kesehatan}

Saat jemaah umrah berada di tanah suci tentunya akan bertemu dengan jamaah umrah dari Negara yang berbeda-beda dengan pola dan perilaku hidup yang berbeda pula, sehingga tidak diketahui penyakit apa yang mereka miliki. Vaksinasi ini dilakukan untuk mencegah dan mengurangi risiko terkena bakteri dan virus berbahaya. Vaksinasi wajib yang telah ditetapkan oleh Kementerian Kesehatan dan Kementerian Agama harus dilakukan untuk semua calon jamaah sebagai salah satu persyaratan dalam pelaksanaan ibadah Umrah untuk mencegah keluar masuknya penyakit.

Jumlahjemaah yang divaksinasimeningitis lebih sedikit dibandingkan jumlah anggota jemaah yang berangkat. Bahkan Kementerian Agama dan PPIU tidak memiliki laporan tentang jemaah yang melaksanakan vaksinasi meningitis. ${ }^{54}$ Jemaah umrah melakukan vaksinasi bertujuan untuk memberikan perlindungan kesehatan jemaah umrah yang dilakukan di Kantor Kesehatan Pelabuhan
(KKP) yang telah diatur dengan rinci dalam PMK No. 12/2017. Pola perilaku jemaah haji yang tidak ingin di vaksinasi merupakan salah satu kendala dalam penyelenggaraan ibadah umrah dan ditemukannya jemaah pemegang kartu International Certificate of Vaccination (ICV) palsu oleh petugas di bandara. ${ }^{55}$

Berdasarkan beberapa permasalahan di atas, maka Negara perlu hadir untuk melindungi hak atas kesehatan jemaah umrah, karena hampir setiap sistem hukum memiliki wewenang dan kewajiban untuk menjaga kesehatan penduduk. ${ }^{56}$ Kewenangan ini berasal dari norma-norma domestik dan internasional. Negara memperoleh kewenangannya melalui konsep kedaulatan: pemerintahan yang berdaulat memiliki kewenangan tunggal untuk membuat undang-undang dan peraturan mengenai kesehatan masyarakat. ${ }^{57}$ Prinsip ini mengakui bahwa risiko tertentu seperti penyakit menular, bencana alam, bahaya industri, makanan dan air yang tercemar serta tindakan yang diperlukan untuk mencegah atau mengurangi risiko tersebut, berada di luar kendali individu atau kelompok. Tidak ada individu yang bertindak sendiri yang dapat menjamin kondisi kesehatan dan keselamatan; hanya Negara yang memiliki kekuatan yang diperlukan untuk campur tangan di tingkat penduduk, melalui tindakan terkoordinasi.

53 Farouk Haffejee, Health Guidelines For Hajj and 'Umrah, Islamic Medical Association of South Africa, 2011. 54 Rustika (b), "Laporan Penelitian: Model Pelayanan Kesehatan Umrah Di Indonesia" (Jakarta, 2016). hlm. 54 55 Ibid. hlm. 55

56 Lawrence O. Gostin and Lindsay F. Wiley, Public Health Law: Power, Duty, Restraint, 3rd ed. (Oakland: University of California Press, 2016).

57 Lawrence O Gostin et al., "The Legal Determinants of Health: Harnessing the Power of Law for Global Health and Sustainable Development," The Lancet 393, no. May 4 (2019), hlm. 1860. 
Banyak instrumen internasional, termasuk konstitusi dan perjanjian WHO, mengatur kewajiban negara untuk melindungi hak-hak terkait kesehatan. Pasal 12 ICESCR dari tahun 1966 berisi tindakan dasar dari hak atas kesehatan. General Comments No. 14 dari Committe on Economic, Social and Cultural Rights(CESCR)menafsirkan danmenguraikan Pasal 12 ICESCR. General Comments on the Right to Health memberikan panduan kepada negara, mengklarifikasi kewajiban dari perjanjian tersebut dan bagaimana mereka seharusnya mengimplementasikannya. ${ }^{58}$ Menurut ICESCR dan General Comments No. 14, hak atas kesehatan adalah "fundamental human right indispensable for the exercise of other human rights", dan "every human is entitled to the enjoyment of the highest attainable standard of health conducive to living a life in dignity". Untuk itu Negara berkewajiban untuk memastikan fasilitas kesehatan yang tersedia (availability), dapat diakses (accessibility), terjangkau (quality), dan dapat diterima (acceptability).

Tabel 2 Implementasi Pemenuhan Hak atas Kesehatan Jemaah Umrah berdasarkan General Comment on the Right to Health

\begin{tabular}{|c|c|c|c|c|}
\hline \multirow{2}{*}{ Tujuan } & \multicolumn{4}{|c|}{ Elemen General Comment on the Right to Health } \\
\hline & Availability & Accesibility & Acceptability & Quality \\
\hline Pembinaan & $\begin{array}{l}\text { Belum adanya program } \\
\text { pembinaan kesehatan } \\
\text { jemaah umrah yang } \\
\text { secara teknis dilakukan } \\
\text { fasilitas kesehatan atau } \\
\text { melalui penyelenggara }\end{array}$ & $\begin{array}{l}\text { Pembinaan kesehatan } \\
\text { belum dirancang untuk } \\
\text { meningkatkan status } \\
\text { kesehatan jemaah } \\
\text { umrah sejak sebelum } \\
\text { keberangkatan }\end{array}$ & $\begin{array}{l}\text { Jemaah umrah pada } \\
\text { dasarnya mau mengi- } \\
\text { kuti seluruh rangkaian } \\
\text { ibadah umrah baik } \\
\text { yang disediakan } \\
\text { penyelenggara maupun } \\
\text { dilakukan secara } \\
\text { mandiri }\end{array}$ & $\begin{array}{l}\text { Sumber daya pelak- } \\
\text { sana pembinaan } \\
\text { kesehatan tersedia di } \\
\text { daerah dengan kualitas } \\
\text { baik dan berpen- } \\
\text { galaman }\end{array}$ \\
\hline Pelayanan & $\begin{array}{l}\text { - Masih terdapat } \\
\text { jemaah yang terlantar } \\
\text { di negara transit } \\
\text { karena sakit } \\
\text { - Adanya kerjasama } \\
\text { antara penyelenggara } \\
\text { dengan fasilitas } \\
\text { pelayanan kesehatan } \\
\text { di Arab Saudi } \\
\text { - Jemaah umrah meny- } \\
\text { iapkan obat-obatan } \\
\text { secara mandiri }\end{array}$ & $\begin{array}{l}\text { - Jemaah umrah } \\
\text { memeriksakan } \\
\text { kesehatannya secara } \\
\text { mandiri saat sebelum } \\
\text { keberangkatan } \\
\text { - Belum adanya } \\
\text { fasilitasi pelayanan } \\
\text { kesehatan saat diper- } \\
\text { jalanan } \\
\text { - Belum adanya } \\
\text { tenaga kesehatan } \\
\text { pendamping }\end{array}$ & $\begin{array}{l}\text { Jemaah umrah pada } \\
\text { dasarnya dapat dan } \\
\text { mau mengikuti seluruh } \\
\text { rangkaian ibadah } \\
\text { umrah baik yang dise- } \\
\text { diakan penyelenggara } \\
\text { maupun dilakukan } \\
\text { secara mandiri, } \\
\text { termasuk dalam } \\
\text { melakukan pemerik- } \\
\text { saan kesehatan }\end{array}$ & $\begin{array}{l}\text { Pada dasarnya sumber } \\
\text { daya pelaksana } \\
\text { pelayanan kesehatan } \\
\text { tersedia di daerah } \\
\text { dengan kualitas baik } \\
\text { dan berpengalaman }\end{array}$ \\
\hline Perlindungan & $\begin{array}{l}\text { KKP melaksanakan } \\
\text { program vaksinasi } \\
\text { bagi jemaah umrah } \\
\text { dan berwenang } \\
\text { menerbitkan ICV } \\
\text { - Masih ada PPIU yang } \\
\text { tidak menyediakan } \\
\text { asuransi kesehatan, } \\
\text { kecelakaan dan } \\
\text { kematian }\end{array}$ & $\begin{array}{l}\text { Untuk memudahkan } \\
\text { akses masyarakat, } \\
\text { beberapa KKP } \\
\text { melakukan kerjasama } \\
\text { dengan fasilitas } \\
\text { kesehatan setempat } \\
\text { untuk dapat melakukan } \\
\text { vaksinasi untuk jemaah } \\
\text { umrah }\end{array}$ & $\begin{array}{l}\text { Masih terdapat jemaah } \\
\text { umrah yang tidak } \\
\text { mau di vaksin, terjadi } \\
\text { pemalsuan ICV, dan } \\
\text { tidak mematuhi waktu } \\
\text { pelaksanaan vaksinasi }\end{array}$ & $\begin{array}{l}\text { Pada dasarnya } \\
\text { sumber daya pelak- } \\
\text { sana perlindungan } \\
\text { kesehatan tersedia di } \\
\text { daerah dengan kualitas } \\
\text { baik dan berpen- } \\
\text { galaman }\end{array}$ \\
\hline
\end{tabular}

58 Nisuke Ando, General Comments/Recommendations. Max Planck Encyclopedia of Public International Law (Oxford: Oxford University Press, 2008). 
Berdasarkan Tabel 2, diperoleh gambaran bahwa pembinaan kesehatan merupakan komponen penting untuk mencapai kemampuan kesehatan jemaah umrah sebelum melaksanakan ibadah umrah. Pembinaan kesehatan berkorelasi dengan hak untuk mencapai standar kesehatan fisik dan mental tertinggi terutama dalam mencapai secara penuh the right to health facilities, goods and services (Pasal 12 ayat (2) butir d CESCR). Standar tersebut mencakup penyediaan akses yang setara dan tepat waktu ke pelayanan kesehatan yang sifatnya preventif dan pendidikan dasar kesehatan. Dalam implementasinya pembinaan kesehatan masih belum dapat memenuhi tingkat esensial minimum dalam General Comments on the Right to Health. Hal ini dapat berdampak pada pemenuhan ketiga unsur lainnya, walaupun fasilitas pelayanan kesehatan di Indonesia mampu melaksanakan kewajiban tersebut. Karena belum adanya regulasi teknis untuk memenuhi hak atas kesehatan jemaah umrah maka pembinaan kesehatan belum dilakukan secara optimal baik oleh penyelenggara maupun Pemerintah sendiri. Sehingga pemenuhan pembinaan kesehatan yang menjadi hak jemaah umrah harus dilakukan dengan kesadaran dan kemandirian jemaah umrah.

Demikian halnya dalam mencapai tujuan dalam pelayanan kesehatan jemaah umrah, dalam implementasinya penyelenggara belum siap menyediakan atau memfasilitasi pelayanan kesehatan jemaah umrah. Dalam konteks pemenuhan hak atas kesehatan dalam General Comments on the Right to Health
Negara dapat menjamin seluruh unsur-unsur esensial yang diperlukan untuk memenuhi hak atas kesehatan jemaah umrah tersebut,. Namun belum secara teknis diatur kewenangan dan penatalaksanaan dalam pemenuhan hak atas kesehatan tersebut, sehingga jelas mana kewajiban negara, PPIU dan tanggung jawab jemaah umrah.

\section{Simpulan}

Kesehatan jemaah umrah telah dijamin oleh Undang-Undang No. 8 Tahun 2019 tentang Penyelenggaraan Ibadah Haji dan Umrah yang diperkuat dengan International Covenant on Economic, Social, and Cultural Rights, International Covenant on Civil and Political Rights 1966.

Berdasarkan analisis tingkat esensial minimum dalam General Comments on the Right to Health terhadap tujuan diselenggarakannya ibadah haji dan umrah, diperoleh hasil bahwa masih ada kendala dalam pemenuhan hak atas kesehatan jemaah umrah yang selama ini menjadi tanggung jawab PPIU, terutama dalam elemen ketersediaan fasilitas kesehatan (availability), diakses pelayanan kesehatan (accessibility). Pemenuhan hak atas kesehatan jemaah umrah tersebut telah diatur dalam Peraturan Menteri Agama RI No. 8 Tahun 2018 Tentang Penyelenggaraan Perjalanan Ibadah Umrah, namun perlu dibuat peraturan oleh menteri yang menyelenggarakan urusan pemerintahan di bidang kesehatan berkolaborasi dengan menteri yang menyelenggarakan urusan pemerintahan di bidang agama. 


\section{DAFTAR PUSTAKA}

Buku

Ando, Nisuke. General Comments/ Recommendations. Max Planck Encyclopedia of Public International Law. Oxford: Oxford University Press, 2008.

Gostin, Lawrence O., and Lindsay F. Wiley. Public Health Law: Power, Duty, Restraint. 3rd ed. Oakland: University of California Press, 2016.

Hadjon, Philip. Perlindungan Hukum Bagi Rakyat Indonesia. Surabaya: Universitas Airlangga, 1985.

Haffejee, Farouk. Health Guidelines For Hajj and 'Umrah. Islamic Medical Association of South Africa, 2011.

Kelsen, Hans. General Theory of Law and State. Translated by Anders Wedberg. New York: Russel \& Russel, 1961.

Mahkamah Konstitusi Republik Indonesia (MK). Naskah Komprehensif Perubahan Undang-Undang Dasar Negara Republik Indonesia Tahun 1945, Latar Belakang, Proses, Dan Hasil Pembahasan 1999-2002. Jakarta: Sekretariat Jenderal dan Kepaniteraan Mahkamah Konstitusi, 2010.

Majelis Permusyawaratan Rakyat Repunlik Indonesia (MPR RI). Risalah Perubahan Undang-Undang Dasar Negara Republik Indonesia Tahun 1945, Tahun Sidang 2000. Buku Dua. Jakarta: Sekretariat Jenderal Majelis
Permusyawaratan Rakyat Republik Indonesia, 2010. - Risalah Perubahan Undang-Undang Dasar Negara Republik Indonesia Tahun 1945, Tahun Sidang 2000. Buku Tujuh. Jakarta: Sekretariat Jenderal Majelis Permusyawaratan Rakyat Republik Indonesia, 2010.

Marks, Stephen P. The Emergence and Scope of the Human Right to Health. Edited by Jose M. Zuniga, Stephen P. Marks, and Lawrence O. Gostin. Advancing the Human Right to Health. Oxford: Oxford University Press, 2013. https:// doi.org/10.1093/acprof.

Mertokusumo, Sudikno. Penemuan Hukum. Bandung: Citra Aditya Bakti, 2009.

Musgrove, Philip. Public and Private Roles in Health: Theory and Financing Patterns. Washington D.C: The World Bank, 1996.

Rahardjo, Satjipto. Ilmu Hukum. Bandung: PT Citra Aditya Bakti, 2000.

\section{Kumpulan Tulisan Dalam Buku}

Musadad, Dede Anwar. "Kebijakan Pelayanan Kesehatan Jemaah Umrah." In Penyelenggaraan Pelayanan Kesehatan Pada Ibadah Umrah, edited by Rustika, 15-40. Jakarta: LIPI Press, 2018.

Puspasari, Herti Windya, Tety Rachmawati, and Rustika. "Prolog: Mewujudkan 
Pelayanan Kesehatan Jemaah Umrah.”

In Penyelenggaraan Pelayanan

Kesehatan Pada Ibadah Umrah, edited by Rustika, 1-14. Jakarta: LIPI Press, 2018.

Rustika, Tety Rachmawati, and Ratih Oemiati. "Efektifitas Pembinaan Jemaah Haji Melalui Posbindu PTM.” In Prosiding Temu Ilmiah Nasional Haji Dan Umrah 2016: "Enhancing Health Promotion and Disease Prevention in Hajj Health Services. Yogyakarta, 25-26 Oktober 2016, 124-32. Jakarta: InternaPublishing, 2016.

\section{Jurnal}

Ardinata, Mikho. "Tanggung Jawab Negara Terhadap Jaminan Kesehatan Dalam Perspektif Hak Asasi Manusia.” Jurnal HAM 11, no. 2 (2020): 319-32.

Arifin, Zaenul, Ahmad Rofiq, and Widayati.

"Reconstruction of Legal Protection for Hajj and Umrah Applicant in Indonesia Based on Justice Value." International Journal of Advanced Research 8, no. 02 (2020): 1374-81. https://doi. org/10.21474/ijar01/10588.

Choi, Kathleen J. “A Journey of a Thousand Leagues: From Quarantine to International Health Regulations and Beyond." University of Pennsylvania Journal of ZInternational Law 29, no. 4 (2014): 989-1022.

Fitranto, Rhezka Imaniar, Andri Dwi Hernawan, and Mardjan. "Analisis
Faktor Yang Berhubungan Dengan Ketepatan Waktu Vaksinasi Meningitis Meningokokus Calon Jemaah Umrah Di KKP Pontianak.” Journal of Health Epidemiology and Communicable Diseases 5, no. 2 (2019): 69-78.

Gostin, Lawrence O, John T Monahan, Jenny Kaldor, Mary Debartolo, Eric A Friedman, Katie Gottschalk, Susan C Kim, et al. "The Legal Determinants of Health: Harnessing the Power of Law for Global Health and Sustainable Development." The Lancet 393, no. May 4 (2019): 1857-1910. https://doi. org/10.1016/S0140-6736(19)30233-8.

Hamzani, Achmad Irwan, Siswanto Siswanto, and Havis Aravik. "Legal Protection for Hajj Pilgrims Through Regional Regulation." Mazahib 17, no. 2 (2018): 61-88. https://doi.org/10.21093/ mj.v17i2.1159.

Mariani, Thohir Luth, M. Hadin Muhjad, and Moh. Fadli. "The Determination of Waiting Listed Pilgrim Candidates Criteria in Hajj Enforcement System in Indonesia." Journal of Law, Policy and Globalization 48, no. 2 (2016): 179-89.

Mukhlis, Sihabudin. "Perlindungan Hukum Jemaah Umrah Dalam Penyelenggaraan Perjalanan Ibadah Umrah.” Asy-Syaria'ah 20, no. 1 (2018): 49-57. https://doi.org/10.1017/ CBO9781107415324.004.

Rustika, Herti Windya Puspasari, and Asep Kusnali. "Analisis Kebijakan Pelayanan 
Vaksinasi Meningitis Jemaah Umrah Di Indonesia." Buletin Penelitian Sistem Kesehatan 21, no. 1 (2018): 60-71.

Salmon-Rousseau, A., E. Piednoir, V. Cattoir, and A. de La Blanchardiere. "HajjAssociated Infections." Medicine et Maladies Infectieuses 46, no. 7 (2016): 346-54. https://doi.org/http://dx.doi. org/10.1016/j.medmal.2016.04.002.

Singka, Eka Jusup, and Innes Ericca. "Hajj Health Management in Indonesia." Medical Journal of Indonesia 29, no. 2 (2020): 117-19. https://doi. org/10.13181/mji.com.204749.

Susanto, Mei, and Teguh Tresna Puja Asmara. "Ekonomi Versus Hak Asasi Manusia Dalam Penanganan COVID-19: Dikotomi Atau Harmonisasi." Jurnal HAM 11, no. 2 (2020): 301-17.

Wilson, Kumanan, Christopher McDougall, David P. Fidler, and Harvey Lazar. "Strategies for Implementing the New International Health Regulations in Federal Countries." Bulletin of the World Health Organization 86, no. 3 (2008): 215-20. https://doi. org/10.2471/BLT.07.042838.

Yamin, Alicia Ely. “The Right to Health Under International Law and Its Relevance to the United States." American Journal of Public Health 95, no. 7 (2005): 1156-61. https://doi.org/10.2105/ AJPH.2004.055111.

Yezli, Saber, Abdulaziz Mushi, Yara Yassin, Fuad Maashi, and Anas Khan.
"Knowledge, Attitude and Practice of Pilgrims Regarding Heat-Related Illnesses during the 2017 Hajj Mass Gathering." International Journal of Environmental Research and Public Health 16, no. 17 (September 3, 2019): 3215. https://doi.org/10.3390/ ijerph16173215.

Yezli, Saber, AbdulazizA. Bin Saeed, Abdullah M. Assiri, Rafat F. Alhakeem, Muslim A. Yunus, Abdulhafiz M. Turkistani, Robert Booy, and Badriah M. Alotaibi. "Prevention of Meningococcal Disease during the Hajj and Umrah Mass Gatherings: Past and Current Measures and Future Prospects." International Journal of Infectious Diseases 47 (2016): 71-78. https://doi. org/10.1016/j.ijid.2015.12.010.

\section{Thesis/Laporan Penelitian}

Roberia. "Paradigma Jaminan Kesehatan Nasional: Konstruksi Jaminan Kesehatan Bagi Seluruh Rakyat Indonesia Dalam Mewujudkan Negara Kesejahteraan Menurut Konstitusi Indonesia." Universitas Indonesia, 2013.

Rustika. "Laporan Penelitian: Implementasi Model Pelayanan Kesehatan Umrah Di Indonesia.” Jakarta, 2017.

"Laporan Penelitian: Model Pelayanan Kesehatan Umrah Di Indonesia.” Jakarta, 2016. 
Zaenal Abidin. Laporan Penelitian: Evaluasi

Implementasi PMA 18 Tahun 2015.

Jakarta: Badan Penelitian dan Diklat

Kementerian Agama, 2016.

\section{Instrumen Internasional}

International Covenant on Civil and Political Rights (ICCPR) (1976).

International Covenant on Economic, Social and Cultural Rights (ICESCR) (1976).

United Nations. Economic and Social Council, U.N. Sub-Commission on Prevention of Discrimination and Protection of Minorities, Siracusa Principles on the Limitation and Derogation of Provisions in the International Covenant on Civil and Political Rights. Annex, UN Doc E/ CN.4/1984/4. Paragraf 25, 1984.

-. "International Covenant on Civil and Political Rights." Database of the United Nations Office of Legal Affairs (OLA), July 4, 2019. https:// www.ohchr.org/Documents/HRBodies/ CCPR/OHCHR_Map_ICCPR.pdf.

- "International CovenantonEconomic, Social and Cultural Rights." Database of the United Nations Office of Legal Affairs (OLA), June 19, 2020. https:// www.ohchr.org/Documents/HRBodies/ CESCR/OHCHR_Map_ICESCR.pdf.

United Nations High Commissioner for Human Rights (UNHCHR) \& World Health Organization (WHO). "The Right to Health.” New York, 2008.
UN General Assembly. Universal Declaration of Human Rights, 10 December 1945, 2015.

World Health Organization. The International Health Regulations (2005). 3rd ed. Geneva: WHO, 2016. https://doi. org/10.1163/15723747-01602002.

\section{Naskah Internet}

Aida, Nur Rohmi. "8 Kebijakan Arab Saudi Mengatasi Corona: Penangguhan Umrah Hingga Penutupan Penerbangan Internasional," March 16, 2020. https://www.kompas.com/tren/ $\mathrm{read} / 2020 / 03 / 16 / 180500265 / 8$ kebijakan-arab-saudi-mengatasicorona--penangguhan-umrah-hinggapenutupan.

Galea, Sandro. "Public Health as a Public Good ," January 10, 2016. https://www. bu.edu/sph/2016/01/10/public-healthas-a-public-good/.

Jayani, Dwi Hadya. “Arab Batalkan Umrah, Berapa Jemaah Indonesia?," March 5, 2020. https://databoks.katadata. co.id/datapublish/2020/03/05/arabbatalkan-umrah-berapa-jemaah-umrahindonesia.

Kementerian Agama RI. "Berapa Jemaah Umrah Dari Indonesia?," March 3, 2017. https://databoks.katadata. co.id/datapublish/2017/03/03/berapajamaah-umrah-indonesia.

Kementerian Kesehatan RI. "Seluruh Jemaah Haji Dan Petugas Akan Divaksinasi 
Meningitis," July 5, 2010. https:// Pettinger, Tejvan. "Healthcare - Private vs www.kemkes.go.id/article/view/1126/ Public Sector ," January 17, 2019. seluruh-jamaah-haji-dan-petugas-akandivaksinasi-meningitis.html.

https://www.economicshelp.org/ blog/1777/economics/health-carePatel, Dipti. "The Hajj and Umrah: Health Protection Matters." Travel Medicine arguments/.

Infectious Diseases 19 (2017). https://

Tempo.co. "Jemaah Umrah Ramadan 2017 doi.org/https://doi.org/10.1016/j. Naik, Indonesia Terbanyak Kedua," tmaid.2017.10.013. June 26, 2017. https://dunia.tempo.co/ $\mathrm{read} / 887362 /$ jemaah-umrah-ramadan2017-naik-indonesia-terbanyak-kedua. 